\title{
Promoting Active Aging in rural Settings: an Intervention Program Implemented in Orense, Spain
}

\section{Promoviendo el envejecimiento activo en entornos rurales: un programa de intervención implementado en Orense, España}

Received: 10 November 2014 | Accepted: 27 January 2017

\author{
Cristina G. Dumitrache \\ Universidad de Granada, España \\ ORCID: http://orcid.org/0000-0001-8340-6476 \\ LAURA Rubio \\ Universidad de Jaén, España \\ IGNACIO BEDOYA \\ Asociación Cuarto Sector Desarrollo Social, España \\ Ramona Rubio-Herrera \\ Universidad de Granada, España
}

\footnotetext{
a Correspondance author. E-mail: cgdumitrache@ugr.es

How to cite: Dumitrache, C. G., Rubio, L., Bedoya, I., \& Rubio-Herrera, R. (2017). Promoting active aging in rural settings: an intervention program implemented in Orense, Spain. Universitas Psychologica, 16(3), 1-12
}

https://doi.org/10.11144/Javeriana.upsy16-3.paar

\begin{abstract}
Promoting health and quality of life among rural older people has received little attention, especially in Spain where the number of interventions designed specifically for the rural elderly is sparse. The aim of this study was to explore the effectiveness of an intervention program aiming at improving quality of life in a group of community-dwelling older adults living in a depopulated rural area in Orense, Galicia, Spain. The sample of this study comprised 86 people (78 people in the intervention group and 8 people in the control group) aged 65 and older $(M=70.82 ; \mathrm{SD}=6.35)$. The evaluation included the MEC, the CDT, and the WHOQOL-Bref questionnaire. The intervention was applied for a period of nine months and consisted of three weekly workshops with a mean duration of four hours that included cognitive stimulation, crafts, and physical activity. The results of the ANCOVA revealed that independently of the age, educational level, gender, and pretest scores, the participants of the intervention group had a lower risk of cognitive impairment. Also they maintained their score on the Psychological health dimension of the WHOQOL-Bref questionnaire while the participants in the control group slightly decreased their score. The intervention program had a positive effect on the participants' perception with regards to their opportunities to participate in leisure activities and improved their cognitive functioning, which in turn contributed to their more positive perception of their psychological health.
\end{abstract}

Keywords

Active aging; quality of life; intervention; rural aging

\section{RESUMEN}

La promoción de la salud y la calidad de vida entre las personas mayores del medio rural ha recibido poca atención, especialmente en España donde el número de intervenciones designadas específicamente para la 
población mayor rural es escasa. El objetivo de este estudio fue explorar la efectividad de un programa de intervención para incrementar la calidad de vida en un grupo de personas mayores que vivían en la comunidad en un área rural despoblada en Orense, Galicia, España. La muestra de este estudio estuvo compuesta por 86 personas (78 en el grupo de intervención y 8 en el grupo control) de 65 o más años $(M=70.82 ; \mathrm{DT}=6.35)$. La evaluación incluyó los cuestionarios MEC, CDT y WHOQOL-Bref. La intervención fue aplicada durante un periodo de nueve meses y consistió en tres sesiones semanales con una duración media de cuatro horas que incluían estimulación cognitiva, actividades físicas y creativas. Los resultados del ANCOVA revelan que independientemente de la edad, nivel educativo, género y puntuaciones pretest, los participantes del grupo de intervención tenían menos riesgo de deterioro cognitivo. Asimismo mantuvieron sus puntuaciones en la dimensión de salud psicológica en el WHOQOL-Bref mientras que los participantes del grupo control disminuyeron ligeramente su puntuación. El programa de intervención tuvo un efecto positivo en la percepción de los participantes respecto a sus oportunidades de participar en actividades de ocio y mejoró su funcionamiento cognitivo lo que finalmente contribuía a una percepción más positiva de su salud psicológica.

Palabras clave

Envejecimiento activo; calidad de vida; intervención; envejecimiento rural

\section{Introduction}

Currently many individuals enjoy high life expectancy although, nevertheless, living longer implies, in many cases, a higher probability of health problems, functional capacity, and quality of life deterioration (Higgs, Hyde, Wiggings \& Blane, 2003; Jylhä, 2004).

This new reality represents an increasing concern for governments worldwide due to the impact that aging has at an economic level in terms of pensions, health, and social security expenditure (Bowling \& Iliffe, 2011). This impact is so noteworthy that social and economic policies need to be adjusted in order to meet the needs of the growing sector of older adults and promote autonomy, health, and quality of life (Bowling, 2004; Bowling \& Iliffe, 2011;Monreal, del Valle \& Tarrés, 2009; Rodríguez-Rodríguez, 2010).

Quality of life is defined as "the individuals' perception of their position in life in the context of the culture and value systems in which they live, and in relation to their goals, expectations, standards, and concerns" (The World Health Organization Quality of Life Group [WHOQOL GROUP], 1994). Although there is no consensus with regard to the definition of quality of life and it is difficult to reach one, it is conceptualized as a multidimensional, multifaceted concept that comprises both objective and subjective dimensions (Bowling, 2004; Bowling \& Windsor, 2001; Smith, Sim, Scharf, \& Phillipson, 2004; Walker \& Lowenstein, 2009; WHOQOL, 1995).

\section{Quality of life models}

Quality of life is a complex construct that comprises many different aspects (Higgs et al., 2003; Walker \& Lowenstein, 2009). Also the variables that constitute it may vary depending on the sample studied, the characteristics of the context where the participants live, the design, and the methodological peculiarities of the study (Smith et al., 2004). As a result there is a sizeable number of quality of life models: objective indicators models, subjective indicators models, need satisfaction models, psychological models, physical functioning models, social functioning models, environmental models, and idiosyncratic models (Bowling, 2004).

At the same time the overlap between the quality of life and subjective indicators of quality of life must also be underlined (Bowling, 2004; Bowling \& Gabriel, 2007). These indicators, like life satisfaction for example, have also been used as criteria to measure successful aging. Thus, quality could be integrated into the successful aging paradigm, as another criterion for aging successfully (Bowling, 2004; Bowling \& Iliffe, 2011).

According to Rowe and Kahn (1997) successful aging can be achieved when a person maintains an excellent health status and eludes illness; has a high rate of physical and mental activity, and is socially engaged. This coincides with the World Health Organization (WHO) proposal of active aging, which is defined as "the process of optimizing opportunities for health, participation, and security in order to enhance 
quality of life as people age" (WHO, 2002). Therefore, active aging emerges as a mean to achieve good quality of life in old age.

\section{Quality of life determinants}

Some of the factors that are directly related to quality of life coincide with the determinants of active aging. These variables can be categorized into three different groups: a biomedical category that includes health and functional status; a psychological group comprising cognitive functioning, emotional functioning, and personality; and a social one that comprehends social relations, social support, social engagement, the environment, and its characteristics.

Physical health and functional status have a major impact on quality of life (Blane, Netuveli \& Montgomery, 2008; Bowling, 2004; Bowling \& Windsor, 2001; Low \& Molzahn, 2007; Michalos, Hubley, Zumbo, \& Hemingway, 2001; Walker $\&$ Lowenstein, 2009). Some health measures that influence the functional status, like the respiratory system or body mass index are associated with quality of life (Blane et al., 2008), especially if said functional status is impaired, then it negatively affects quality of life (Netuveli, Wiggins, Hildon, Montgomery, \& Blane, 2005). Subjective health is another important predictor (Smith et al., 2004) explaining up to 35 percent of the variance in quality of life (Michalos et al., 2001).

Among the psychological predictors of quality of life, cognitive functioning stands out as a relevant factor. For example, older people who experience an abrupt deterioration of cognitive capacities are more impaired when it comes to perform daily activities and tasks, and have a higher mortality risk compared to those with good cognitive functioning (Yaffé et al., 2010). Thus, an excellent cognitive state is essential for quality of life, autonomy, and productivity (Desai, Grossberg, \& Chibnall, 2010). Likewise, emotional disorders and negative emotional states can be detrimental for quality of life, for example depression and loneliness are associated with low quality of life (Blane et al., 2008; Smith et al., 2004).

Social relations, social support, the resources available in the neighboring contexts, accessibility, satisfaction with the neighborhood, and social participation are also prominent determinants of quality of life (Bowling, 2004; Bukov, Maas, \& Lampert, 2002; Ekström, Dahlin, \& Elmstahl, 2008; Netuveli et al., 2005; Smith et al., 2004). Social contacts are a source of satisfaction and quality of life for older people (Cheng, Chan, \& Phillips, 2004; Instituto de Mayores y de Servicios Sociales [IMSERSO], 2009), especially when they afford emotional support (Low \& Molzahn, 2007). In addition, a social context that provides social interaction opportunities allows goal attainment and leisure activities which increases quality of life (Low \& Molzahn, 2007). Being satisfied with the neighborhood and living in a context free of physical obstacles also contributes to high quality of life (Netuveli et al., 2005; Smith et al., 2004).

\section{Programs aiming at improving quality of life}

Numerous programs developed in the gerontological context were aimed at maintaining and improving cognitive functioning, or at preserving a good physical status. Meanwhile only a limited number of interventions include other aspects that have also been found to improve quality of life, like leisure activities (Cardenas, Henderson, \& Wilson, 2009).

Regarding interventions that include cognitive or physical activities, review studies (e.g. Jean, Bergeron, Thivierge, \& Simard, 2010; Tardif \& Simard, 2011) highlight their utility, since they promote a good mental state, wellbeing, and quality of life. Nevertheless, there is also evidence that interventions that combine both cognitive stimulation and physical activity have a stronger impact on both cognitive and emotional states than single-component programs (Fabre, Chamari, Mucci, Massé-Biron, \& Préfaut, 2002; Rey, Canales, \& Táboas, 2011; Valencia et al., 2008). Consequently, 
it is necessary to develop interventions that include physical, cognitive, and leisure activities (Cardenas et al., 2009; Hui \& Rubenstein, 2006).

Promoting quality of life in rural contexts

Promoting health and quality of life among rural older people has received little attention (Milne, Hatzidimitriadou, \& Wiseman, 2007). In Spain, rural aging has not been studied in depth (Monreal et al., 2009; Triadó, Villar, Solé, \& Osuna, 2003) despite the fact that, as RodríguezRodríguez (2004) states, aging in a village or in a city is essentially different.

The unbalanced distribution of resources offered to older people that live in rural and urban areas is noteworthy in Spain. While the elderly from urban contexts are provided with more resources and have more possibilities to be socially engaged and to take part in leisure activities, rural older adults count on a limited offer of this kind of activities (García-Sanz, 1997; Rodríguez-Rodríguez, 2004; Wilcox, Bopp, Oberrecht, Kammerman, \& McElmurray, 2003). As a consequence, older adults from rural areas have a reduced probability to age successfully.

Conversely, Spanish aging polices do not give specific recommendations about older people from rural areas and the number of interventions designed specifically for them is sparse (García-González \& Rodríguez-Rodríguez, 2005). Therefore, it seems that intervention programs that aim at maintaining quality of life in Spanish rural contexts are particularly necessary. Rodríguez-Rodríguez (2004) states that these kind of programs should focus on two aspects: on the one hand, promoting active aging and, on the other hand, fostering proximity services that provide formal support to older adults with high disability rates and to their caregivers.

Until recently, the quality of life intervention programs developed in rural areas in Spain (García-González \& Rodríguez-Rodríguez, 2005; Monreal \& Vilà, 2008) have specifically concentrated on community social intervention; one of the programs we identified aimed at establishing a reference centre for social intervention in a rural area (Monreal \& Vilà, 2008), and the other one (Rodríguez-Rodríguez, 2004) had the goal to create new services and resources in rural communities, such as accessible transport, delivery of technical aids, and the establishment of older adults associations that would develop cultural activities. None of them included aspects related with participants' physical or psychological functioning. For this reason, we acknowledge the need to design an intervention program that contemplates physical status, cognitive function, and leisure activities.

Considering all it has been previously discussed, the goal of this study is to analyze the effectiveness of an intervention program aiming at improving quality of life through cognitive stimulation, physical, and crafts activities in a group of community-dwelling older adults living in a rural context in Orense, Galicia, Spain.

\section{Methods}

\section{Participants and recruitment}

The sample comprised 86 older adults (78 participants in the intervention group; 8 participants in the control group) aged 65 and older from 11 villages of a rural area with high rates of depopulation and aging in Orense, Spain. The control group was considerably reduced due to the terms and conditions of the sponsoring organisms that could only provide finance for the intervention program to be implemented for a limited period of time.

This research was approved by the committee and head of the foundation that sponsored the study, Fundación Barrié de la Maza, and the village councils which collaborated in the study. Also, prior to the start of the intervention the participants gave their informed consent.

\section{Materials}

Demographic characteristics included gender, age, educational level, income, and living arrangements. 
Mini-Examen Cognoscitivo (MEC) (Lobo, Esquerra, Gómez Burgada, Sala, \& Seva, 1979) Spanish version of Mini-Mental State Examination comprises 11 items that screen cognitive impairment by assessing 5 cognitive areas: orientation (temporal and spatial), attention and calculation, word recall, language, and visuospatial abilities. The maximum score for the Spanish version that has been used in this research is 35 points and any score lower than 24 point suggests cognitive impairment, specifically mild (23-21 points), moderate (20-11 points) and severe ( $\leq 10$ points). According to Lobo et al. (1999) the MEC correlates with the Wechsler Adults Intelligence Scale (WAIS) and with clinical examinations of intelligence.

Clock Drawing Test (CDT) (Cacho, García, Arcaya, Vicente, \& Lantada, 1999) is a widely used instrument that screens cognitive impairments. It is divided in two parts, first, the patient is asked to draw a clock with the dial, all the numbers, and set the hands at ten past eleven. After that, the subject has to copy the drawing of the clock. Normal cognitive functioning is assumed if scores are 6 or higher for the first part and of 8 or higher for the copy.

WHOQOL-BREF (WHOQOL Group, 1998) is an abbreviated version of the WHOQOL-100 that comprises a total of 26 Likert items with 5 response options (from $1=$ nothing to $5=$ completely). The items are grouped into four domains: physical health, psychological health, social relationships, and environment. The WHOQOL-BREF has a correlation of 0.90 withthe original version of 100 items and has good discriminant, content validity, and testretest reliability. In the present study, the Spanish version (Lucas, 1998) showsgood reliability $(\alpha$ $=0.80$ to 0.82 ).

\section{Interventions}

The cognitive stimulation workshop was designed to promote good cognitive functioning and included the following activities: calculation, attention, reasoning, spatial orientation, time orientation, linguistic-factors related exercises, memory, seriation, planning and categorization tasks, and information on healthy habits that prevent cognitive impairment.

The crafts workshop was aimed at maintaining and improving dexterity and manual skills, and at encouraging creativity and promoting social interaction. The group of elderly met twice a week to decorate pottery and recycled objects, and to make jewerly.

Exercise workshop was aimed at improving the well-being and physical health of participants, enhancing mobility, and autonomy. Each session began with warm up and stretching exercises, and continued with the activities and exercises chosen for that session. At the end of the session the intensity of the activity was reduced and stretching exercises were performed again. Seven different exercise routines were designed that were cyclically repeated until the intervention program finished. These exercises consisted of aerobics, fitness, dumbbell exercises, mate exercises and stretching, choreography using sticks and gymnastics balls.

\section{Procedure}

The pre-test assessment was conducted during January $1^{\text {st }} 2011$ using the questionnaire on demographic characteristics, the MEC, the CDT, and the WHOQOL-BREF. The intervention program was developed between March and December 2011, four hours a week for each workshop. After finishing the intervention program the MEC, the CDT, and the WHOQOL-BREF were administered for the post-test assessment. The assessment of each participant lasted between 45 and 60 minutes, and data collection and implementation of the intervention program were conducted by previously trained staff.

\section{Statistical analysis}

A cross-sectional correlational of non-equivalent groups design was used. Preliminary analyses were performed to test differences between 
the control and the intervention group with respect to their demographic characteristics and the pretest scores for the MEC, CDT, and the WHOQOL-BREF. Also, the effect of age and educational levels on the MEC, the CDT, and the WHOQOL-BREF dimensions were analyzed using T-tests and analysis of variance (ANOVA). In order to determine if there were significant differences between the intervention and the control group in posttest WHOQOLBREF, MEC, and CDT regardless of covariates, several analysis of covariance (ANCOVA) were conducted. Changes in quality of life and cognitive functioning (i.e., improvement or deterioration) were considered significant if $\mathrm{p}<$ 0.05 .

\section{Results}

\section{Descriptive statistics}

Table 1 shows the means and standard deviations of the study variables and the demographic characteristics for the control and the intervention group. In the intervention group the majority of the participants were female while in the control group the majority was male. The mean age of the participants in the intervention group was $68.77 \pm 8.97$ while the mean age for the participants in the control group was 76.29 \pm 4.54 , these differences in the mean age were statistically significant $(t(83)=2.183, p<0.05$, $\eta 2 p=0.05)$. Similar educational level and pretest scores were observed for the participants in both the control and the experimental groups in the MEC, the CDT, and WHOQOL dimensions, as no statistical significant differences were found between them $(p>0.05)$.
TABLE 1

Descriptive statistics for study variable by group

\begin{tabular}{|c|c|c|c|c|}
\hline & \multicolumn{2}{|c|}{$\begin{array}{l}\text { Intervention group } \\
(\mathrm{N}=78)\end{array}$} & \multicolumn{2}{|c|}{$\begin{array}{l}\text { Control group } \\
(\mathrm{N}=8)\end{array}$} \\
\hline Variables & \multicolumn{2}{|c|}{ Percent } & \multicolumn{2}{|c|}{ Percent } \\
\hline \multicolumn{5}{|l|}{ Gender } \\
\hline Male & \multirow{2}{*}{\multicolumn{2}{|c|}{$\begin{array}{l}24.4 \\
75.6\end{array}$}} & \multicolumn{2}{|c|}{75} \\
\hline Female & & & \multicolumn{2}{|c|}{25} \\
\hline \multicolumn{3}{|l|}{ Educational level } & & \\
\hline Illiterate & \multicolumn{2}{|c|}{1.3} & \multicolumn{2}{|c|}{ - } \\
\hline Reads and writes & \multicolumn{2}{|c|}{24.4} & \multicolumn{2}{|c|}{25} \\
\hline Primary incomplete & \multirow{2}{*}{\multicolumn{2}{|c|}{$\begin{array}{l}20.5 \\
53.8\end{array}$}} & \multirow{2}{*}{\multicolumn{2}{|c|}{$\begin{array}{l}25 \\
50\end{array}$}} \\
\hline Primary complete & & & & \\
\hline Variables & Mean & $S D$ & Mean & $S D$ \\
\hline Age & 68.77 & 8.97 & 76.29 & 4.54 \\
\hline \multicolumn{5}{|l|}{ Study variable } \\
\hline Pretest MEC & $27.29 * * *$ & 4.04 & 27.38 & 3.74 \\
\hline Posttest MEC & $30.50^{* * *}$ & 3.54 & $26.25 * * *$ & 3.28 \\
\hline Pretest CDT & $5.62 * * *$ & 3.19 & 4.62 & 3.66 \\
\hline Posttest CDT & $7.17 * *$ & 2.75 & $6.25 * *$ & 1.48 \\
\hline Pretest General QL & 3.28 & 0.88 & 3 & 0.93 \\
\hline Posttest General QL & 3.31 & 0.79 & 2.50 & 1.07 \\
\hline $\begin{array}{r}\text { Pretest General } \\
\text { Health }\end{array}$ & 3.38 & 1.15 & 2.38 & 0.92 \\
\hline $\begin{array}{r}\text { Posttest General } \\
\text { Health }\end{array}$ & 3.45 & 1.09 & 2.50 & 0.93 \\
\hline $\begin{array}{r}\text { Pretest Physical } \\
\text { Health }\end{array}$ & 25.17 & 4.22 & 22.50 & 3.82 \\
\hline $\begin{array}{r}\text { Posttest Physical } \\
\text { Health }\end{array}$ & 25.30 & 4.14 & 21.88 & 5.72 \\
\hline \multicolumn{5}{|l|}{$\begin{array}{l}\text { Hetestn } \\
\text { Pretst }\end{array}$} \\
\hline Psychological & 21.49 & 3.73 & 20.75 & 4.43 \\
\hline Health & & & & \\
\hline \multicolumn{5}{|l|}{ Posttest } \\
\hline $\begin{array}{r}\text { Psychological } \\
\text { Health }\end{array}$ & $21.91^{* * *}$ & 4.04 & $19.12^{* * *}$ & 4.08 \\
\hline $\begin{array}{r}\text { Pretest Social } \\
\text { Relationship }\end{array}$ & 10.88 & 1.97 & 10.63 & 1.19 \\
\hline $\begin{array}{l}\text { Posttest Social } \\
\text { Relationship }\end{array}$ & 10.88 & 1.97 & 10.63 & 1.19 \\
\hline Pretest Environment & 25.10 & 4.61 & 24 & 4.24 \\
\hline $\begin{array}{r}\text { Posttest } \\
\text { Environment }\end{array}$ & $21.61 * * *$ & 4.43 & $19 * * *$ & 1.60 \\
\hline
\end{tabular}

Note: MEC: Mini-Examen Cognoscitivo (Spanish version of Mini-Mental State Examination); CDT: Clock Drawing test; General QL: WHOQOL-BREF Item 1; $*_{p}<0.05 ; * * p<0.01 ; * * p<0.001$. Source: own work.

Effects of the intervention on cognitive functioning and quality of life

Preliminary analysis revealed that educational level was associated with statistically significant differences in the pre-test MEC score $(F(3)=$ 121.139, $p<0.001, \eta 2 p=0.31)$; participants without formal education scored higher than those with primary incomplete education $(p<$ 0.01 ) and participants with complete primary education scored higher than those with incomplete primary education $(p<0.001)$. Statistically significant differences were also found for the pre-test CDT score by educational level $(F(2)=11.262, p<0.001, \eta 2 p=$ 0.21 ) between the highest scoring group with complete primary education and the lowest 
scoring group of participants with incomplete primary education $(p<0.001)$, and between participants without formal education and those with primary incomplete education $(p<0.05)$.

Educational level was also associated with statistically significant differences in the WHOQOL-BREF physical health domain $(F(2)$ $=4.279, p<0.05, \eta 2 \mathrm{p}=.09)$. Participants with complete primary education scored significantly higher than those with incomplete primary education $(p<0.05)$. Also, educational level was linked with statistically significant differences in the WHOQOL-BREF environment dimension $(F(2)=3.357, p<0.05, \eta 2 \mathrm{p}=0.08)$, participants without formal education scored significantly higher than those with incomplete primary education $(p<0.05)$.

Similarly educational level had a statistically significant effect on MEC post-test $(F(2)=$ 10.573, $p<0.001, \eta 2 p=0.24)$, participants with incomplete primary education obtained the lowest score when compared with participants without formal education $(p<0.05)$, and with those with complete primary education $(p<0.001)$. Statistically significant differences were also found for the post-test CDT score by educational level $(F(2)=3.46, p<$ $0.05, \eta 2 \mathrm{p}=0.09$ ) between participants with complete primary education, who obtained the highest score, and those with incomplete primary education who obtained the lowest score $(p<$ 0.05).

The ANCOVA analysis revealed that after removing the covariate influence of age, educational level, gender, and the pretest scores, statistically significant differences in the posttest scores were found between the participants in the intervention and the control group. Participants in the intervention group had significantly higher scores in posttest MEC $(F=5.853 ; p<0.001)$, CDT $(F=4.141 ; p<0.01)$, psychological health $(F=9.651 ; p<0.001)$, and environment dimension $(F=15.010 ; p<0.001)$. All ANCOVAs had very high power once covariate influence was removed.

After the nine months intervention program, significant differences in pre-test and post-test scores were found in the intervention group, both for the MEC $(t(62)=-7.432, p<0.001, \eta 2 \mathrm{p}$ $=0.47$ ) (see Figure 1) and the CDT $(t(62)=$ -3.974, $p<0.001, \eta 2 p=0.20)$, while in the control group the average scores were similar in the first and second measurement (see Table 1).

Figure 1.

MEC pre-test and post-test scores for the

Intervention and the Control Group

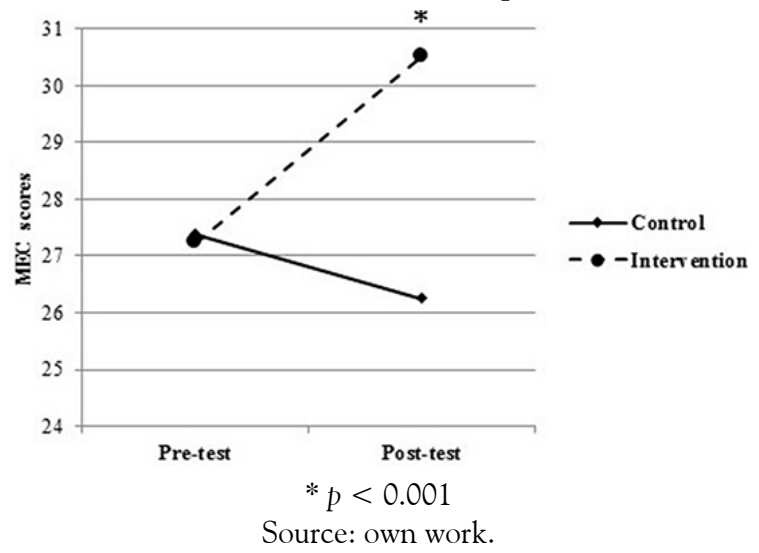

At the same time, while the intervention group obtained similar scores in the pre-test and the post-test score for the psychological health, the control group slightly decreased their score $(t(7)$ $=4.333, p<0.01, \eta 2 p=0.72$ ).

On the contrary, the score in the Environment dimension of the WHOQOL-BREF significantly decreased for both the intervention $(t(63)=$ 9.022, $p<0.001, \eta 2 \mathrm{p}=0.56)$ and the control group $(t(7)=4.830, p<0.01, \eta 2 p=0.77)$; nevertheless, the difference between the pretest and post-test score was smaller for the intervention group than for the control group (see Table 1).

Also, when each question of the WHOQOLBREF was analyzed independently, it was found that, when asked about the opportunities for leisure activities, participants in the intervention group scored higher in the post-test evaluation $(t(63)=-4.277, p<0.001, \eta 2 p=0.22)$ while no difference was found for the control group.

\section{Discussion}

The aim of this study was to analyze the effectiveness of an intervention program aiming 
at improving quality of life through cognitive stimulation, physical, and group crafts activities in a group of community-dwelling older adults living in a rural context.

It was found that after the intervention, the participants in the intervention group considered they had more opportunities for performing leisure activities. As some authors have emphasized (García-Sanz, 1997; RodríguezRodríguez, 2004; Wilcox et al., 2003), the rural elderly have very little possibilities to participate in leisure activities that allow them to age actively, and the number of interventions designed specifically for them is sparse (GarcíaGonzález \& Rodríguez-Rodríguez, 2005), which constitutes a disadvantage. In the rural area where the program was applied, formal social resources that provide opportunities for social participation and leisure activities are exiguous and taking part in a nine month intervention program with weekly sessions of physical, cognitive, and crafts activities emerged as a great opportunity to increase their probability to age actively. It was found that taking part in this program was associated with a lower risk of cognitive impairment.

Regarding quality of life, we found that when age, educational level, gender, and pretest scores were controlled, the intervention group also maintained a more positive perception of their psychological health than the control group. These results are in tune with findings from the review studies on the effectiveness of cognitive stimulation programs (Jean et al., 2010; Tardif \& Simard, 2011), which underline the fact that these interventions contribute to the maintenance of a good cognitive state and even to the improvement of cognitive functioning. As Jean et al. (2010) emphasize, the majority of programs of cognitive stimulation are usually effective in improving quality of life, emotional state, and memory.

At the same time, the results of this study provide evidence with regard to the effectiveness of multicomponent interventions when aiming at maintaining cognitive functioning. Rey et al. (2011) found that the participants of their multicomponent program rated their emotional state as being better after taking part in the cognitive stimulation and physical activities. In our study, after the intervention, the participants rate their psychological health as being better in comparison to the pre-test, although the psychological health includes both cognitive and emotional aspects, and for this reason, we cannot consider which of these two aspects the program had a higher impact on.

On the contrary, no effect was found for the rest of the quality of life dimensions and on the environment dimension the participants even obtained a lower score after the intervention. This result could be explained by the fact that participants' initial expectation, their motivations to participate in the program, their self-efficacy, and their personality have not been considered. Several authors stress the importance of psychological and subjective perceptions of individuals when explaining quality of life (Bowling, 2004; Bowling \& Gabriel, 2007; Bowling \& Iliffe, 2011). As Bowling and Iliffe assert, it is essential to consider the impact of this kind of psychological variables, when designing interventions aiming at increasing quality of life. Also, it is likely that the results on the physical health domain might be explained by the fact that it is not enough with providing physical exercise opportunities and cognitive stimulation, but it is also necessary to inform the participants about the benefits of physical exercise and to include other healthy lifestyle habits apart from physical exercise.

In addition, macro-societal aspects, such as economic and social resources, housing or the social cohesion that characterize the environment where the participants live have not been considered in the intervention, and this aspect might explain why the participants obtained lower scores on the environment domain of the WHOQOL-BREF after the intervention. The intervention program did not contemplate improving the formal support available, therefore the participants continued to feel dissatisfied with their environment, and maybe they even changed their expectation with regards to their access to information and services after the program, which could 
explain why they scored lower. As some authors have underlined, environmental aspects could significantly influence older people's quality of life (Bowling, 2004; Walker \& Lowenstein, 2009), in this way, the results of the present study could be mediated by the fact that the participants belong to a rural area where the public administrations do not adapt the services they provide to the needs of the rural elderly. Therefore in future studies that aim at improving quality of life in old age, macrosocietal and other contextual characteristics of the environment where the intervention is going to be applied should be taken into account, considering the constrains and the weaknesses of the environment.

Other limitations must also be acknowledged. The frequency of participation in the intervention program of the elderly taking part in this study has not been controlled. This aspect could influence the results obtained, as attending more frequently the proposed activities could have a stronger effect on quality of life; therefore future studies should contemplate this aspect.

At the same time, the effect that each type of activity has cannot be decomposed, since there was only one intervention group that took part in all the activities proposed. Interventions that last longer, have larger control groups and several interventional groups would allow studying the composed and separated effect of the different activities proposed in our study. Likewise the control group was excessively reduced and the design used in this study did not allow a random assignment of the participants to the intervention and the control group, thus it might be possible that participants with a better cognitive functioning and a higher quality of life, or more motivated to participate have selfselected themselves to take part in the study. The lack of randomization is a weakness to this study that limits its generalizability. Owing to it, future interventional studies should use random procedures to select participants, have several intervention groups, and a wider control group.

With regard to the instruments we used, it is important to highlight the fact that the MEC is sensible to age and educational effect.
At the same time, because it is a screening tool, it only assesses the absence or presence of cognitive impairment and does not evaluate cognitive functioning; therefore the impact of the intervention on different cognitive functions cannot be assessed. Similarly, the WHOQOLBREF is a self-reported instrument and it only evaluates the participants' perception with regards with several domains of quality of life. Because of the limitations of the self-reported instruments, it would be advisable that future studies should include objective measures of both cognitive functioning and quality of life.

Another limitation of the present study is the fact that the intervention sessions were designed as group activities. As Rey et al. (2011) emphasize, group activities have a positive effect on quality of life per se, and this could have influenced the results obtained. It would be interesting to consider the individual versus group implementation as a possible covariable that could impact on the effectiveness of the intervention.

Despite limitations, the present study contributes to extending the knowledge on quality of life promotion. It highlights the positive effect of multicomponent interventions to maintain good cognitive functioning and foster a positive perception with regard to leisure opportunities and psychological health among the elderly. It is desirable to continue developing interventions that promote active aging and quality of life in rural settings in order to allow the rural older adults to be socially engaged and generate new strategies to deal with the changing circumstances they have to face.

\section{Acknowledgements}

The Active Aging program developed in Orense was financed by Fundación Barrié and Cáritas Diocesana Orense, and carried out by Cáritas Diocesana Orense and the research group HUM867: Gerontology of University of Granada. 


\section{References}

Blane, D., Netuveli, G., \& Montgomery, S. M. (2008). Quality of life, health and physiological status and change at older ages. Social Sciences and Medicine, 66(7), 1579-1587. http://dx.doi.org/10.1016/ j.socscimed.2007.12.021

Bowling, A. (2004). A taxonomy and overview of quality of life. In J. Brown, A. Bowling \& T. Flynn (Eds.), Models of quality of life: A taxonomy and systematic review of the literature (pp. 6-12). Sheffield: European Forum on Population Ageing Research.

Bowling, A., \& Gabriel, Z. (2007). Lay theories of quality of life in older age. Ageing $\mathcal{E}$ Society, 27, 827-848. https:// doi.org/10.1017/S0144686X07006423

Bowling, A., \& Iliffe, S. (2011). Psychological approach to successful ageing predicts future quality of life in older adults. Health and Quality of Life Outcomes, 9, 13. http:// dx.doi.org/10.1186/1477-7525-9-13

Bowling, A., \& Windsor, J. (2001). Towards the good life: A population survey of dimensions of quality of life. Journal of Happiness Studies, 2, 55-81. http:// dx.doi.org/10.1023/A:1011564713657

Bukov, A., Maas, I., \& Lampert, T. (2002). Social participation in very old age: Crosssectional and longitudinal findings from BASE. Journals of Gerontology, Series B, 57(6), 510-517.

Cacho, L. J., García-García, R., Arcaya, J., Vicente, J. L., \& Lantada, N. (1999). Una propuesta de aplicación y puntuación del Test del Reloj en la enfermedad de Alzheimer. Revista de Neurología,28, 648-655.

Cardenas, D., Henderson, K. A., \& Wilson, B. E. (2009). Physical activity and senior games participation: Benefits, constraints, and behaviors. Journal of Aging and Physical Activity, 17(2), 135-153.

Cheng, S. T., Chan, A. C. M., \& Phillips, D. R. (2004). Quality of life in old age: An investigation of well older persons in Hong Kong. Journal of Community Psychology,
32(3), 309-326. http://dx.doi.org/10.1002/ jcop.20003

Desai, A. K., Grossberg, G. T., \& Chibnall, J. T. (2010). Healthy brain aging: A road map. Clinics in Geriatric Medicine,26(1), 1-16. http:// dx.doi.org/10.1016/j.cger.2009.12.002

Ekström, H., Dahlin-Ivanoff, S., \& Elmståhl, S. (2008). Restriction in social participation and lower life satisfaction among fractured in pain: Results from the population study "Good Aging in Skåne". Archives of Gerontology and Geriatrics, 46(3), 409-424. http://dx.doi.org/10.1016/ j.archger.2007.06.001

Fabre, C., Chamari, K., Mucci, P., Massé-Biron, J., \& Préfaut, C. (2002). Improvement of cognitive function by mental and/or individualized aerobic training in healthy elderly subjects. International Journal of Sports Medicine, 23, 415-421. http:// dx.doi.org/10.1055/s-2002-33735

García-González, J., \& Rodríguez-Rodríguez, P. (2005). Rompiendo distancias: un programa integral para prevenir y atender la dependencia de las personas mayores en el medio rural. Revista Española de Geriatría y Gerontología, 40(1), 22-33.

García-Sanz, B. (1997). Envejecimiento y mundo rural: problemas y soluciones. Madrid: IMSERSO.

Higgs, P., Hyde, M., Wiggins, R., \& Blane, D. (2003). Researching quality of life in early old age: The importance of the sociological dimension. Social Policy and Administration, 37, 239-252. http:// dx.doi.org/10.1111/1467-9515.00336

Hui, E. K., \& Rubenstein, L. Z. (2006). Promoting physical activity and exercise in older adults. Journal of the American Medical Directors Association, 7(5), 310-314. http:// dx.doi.org/10.1016/j.jamda.2006.03.006

Instituto de Mayores y Servicios Sociales. (2009). Las Personas Mayores en España (Informe 2008. Documento Estadístico N. ${ }^{\circ}$ 22018). Madrid: Ministerio de Trabajo y Asuntos Sociales. Recuperado de http://www.imsers omayores.csic.es/documentos/estadisticas/i 
Promoting Active Aging in rural Settings: an Intervention Program Implemented in Orense, Spain *

nforme-mayores/2008/volumen-1/00-infor me-personas-mayores-2008-vol-01.pdf

Jean, L., Bergeron, M. E., Thivierge, S., \& Simard, M. (2010). Cognitive intervention programs for individuals with mild cognitive impairment: Systematic review of the literature. The American Journal of Geriatric Psychiatry, 18(4), 281-296. http:// dx.doi.org/10.1097/JGP.0b013e3181c37ce9

Jylhä, M. (2004). Old age and loneliness: Cross-sectional and longitudinal analyses in the tamper longitudinal study on aging. Canadian Journal of Aging, 23(2), 157-168.

Lobo, A., Esquerra, J., Gómez Burgada, F., Sala, J. M., \& Seva, A.(1979). El Mini-Examen Cognoscitivo: un test sencillo y práctico para detectar alteraciones intelectuales en pacientes médicos. Actas Luso Españolas de Neurología, Psiquiatría y Ciencias Afines, 3, 189-202.

Lobo, A., Saz, P., Marcos, G., Día, J. L., De la Cámara, C., Ventura, T., ... Aznar, S. (1999). Revalidación y normalización del Mini-Examen Cognoscitivo (primera versión en castellano del MiniMental Status Examination) en la población general geriátrica. Medicina Clínica,112(20), 767-774.

Low, G., \& Molzahn, A. E. (2007). Predictors in quality of life in old age: A Cross-validation study. Research in Nursing and Health, 30(2), 141-150.

Lucas, C. R. (1998). Versión Española del WHOQOL. División de Salud Mental, Organización Mundial de la Salud. Madrid: Ergon.

Michalos, C., Hubley, A. M., Zumbo, B. D., \& Hemingway, D. (2001). Health and other aspects of the quality of life of older people. Social Indicators Research,54(3), 239-274.

Milne, A., Hatzidimitriadou, E., \& Wiseman, J. (2007). Health and quality of life among older people in rural England: Exploring the impact and efficacy of policy. Journal of Social Policy, 36(3), 477-495. https:// doi.org/10.1017/S0047279407001055

Monreal, P., del Valle, A., \& Tarrés, R. (2009). Hacer visible lo invisible: Peralada un estudio de caso. Anuario de Psicología, 40(3), 391-406.

Monreal, P., \& Vilà, A. (2008). Programa integral de atención a las personas mayores en una zona rural. Anuario de Psicología, 39(3), 351-370.

Netuveli, G., Hildon, Z., Montgomery, S., Wiggins, R., \& Blane, D. (2005). Need for change in focus from illness to functioning to improve quality of life: Evidence from a national survey. British Medical Journal, 331, 1382-1383. http://dx.doi.org/10.1136/ bmj.331.7529.1382

Rey, A., Canales, I., \& Táboas, M. I. (2011). Características y efectos de un programa integrado de estimulación cognitiva a través de la motricidad. Apunts: Educación Física y Deportes, 105, 21-27.http:// dx.doi.org/10.5672/apunts.2014-0983.es

Rodríguez-Rodríguez, P. (2004). Envejecimiento en el mundo rural: necesidades singulares, politicas específicas. Madrid: IMSERSO.

Rodríguez-Rodríguez, P. (2010). La atención integral centrada en la persona. Madrid: IMSERSO.

Rowe, J. W., \& Kahn, R. L. (1997). Successful aging. The Gerontologist, 37(4), 433-440.

Smith, A. E., Sim, J., Scharf, T., \&Phillipson, C. (2004). Determinants of quality of life amongst older people in deprived neighbourhoods. Ageing and Society, 24(5), 793-814. https://doi.org/10.1017/ S0144686X04002569

Tardif, S., \& Simard, M. (2011). Cognitive stimulation programs in healthy elderly: A review. International Journal of Alzheimer's Disease, 37893. http:// dx.doi.org/10.4061/2011/378934

Triadó, C., Villar, F., Solé, C., \& Osuna, M. J. (2003). Envejecer en entornos rurales (Estudios de I+D+I. N. ${ }^{\circ}$ 19). Madrid: IMSERSO.

Valencia, C., López-Alzate, E., Tirado, V., ZeaHerrera, M. D., Lopera, F., Rupprecht, R., \& Oswald, W. D. (2008). Efectos cognitivos de un entrenamiento combinado de memoria y psicomotricidad en adultos 
mayores. Revista de Neurología, 46(8), 465-471.

Walker, A., \& Lowenstein, A. (2009). European perspectives on quality of life in old age. European Journal of Ageing, 6, 61. http:// dx.doi.org/10.1007/s10433-009-0117-9

World Health Organization [WHO]. (2002). Active ageing: A policy framework[Resource document. $\mathrm{N}^{\circ} \mathrm{WHO} /$ NMH/NPH/02.8]. Madrid: Author. Retrieved from http://apps.who.int/iris/bits tream/10665/67215/1/WHO_NMH_NPH 02.8.pdf

The World Health Organization Quality of Life Group. (1994). Development of the WHOQOL: Rationale and current status. International Journal of Mental Health, 23, 24-56.

The World Health Organization Quality of Life Group. (1995). The World Health Organization Quality of Life Assessment (WHOQOL) [Position Paper from the World Health Organization]. Social Science Eु Medicine,41 (10), 1403-1409.

The World Health Organization Quality of Life Group. (1998). Development of the World Health Organization WHOQOL-BREF quality of life assessment. Psychological Medicine, 28, 551-558.

Wilcox, S., Bopp, M., Oberrecht, L., Kammermann, S. K., \& McElmurray, C. T. (2003). Psychosocial and perceived environmental correlates of physical activity in rural and older African American and white women. Journals of Gerontology: Series B, 58, 329-337.

Yaffé, K., Lindquist, K., Vittinghoff, E., Barnes, D., Simonsick, E. M., Newman, A., ... Harris, T. (2010). The effect of maintaining cognition on risk of sisability and death. Journal of the American Geriatrics Society, 58(5), 889-894. http://dx.doi.org/10.1111/ j.1532-5415.2010.02818.x

\section{Notes}

* Research article. 